\title{
Radon in Ground Water in Seven Counties of Wyoming
}

\section{RADON SAMPLING IN WYOMING}

Radon is a concern of many residents in Wyoming because breathing air containing high levels of radon poses a health risk. Radon is second only to cigarette smoking in causing lung cancer in the United States and is estimated to cause between 5,000 and 20,000 lung-cancer fatalities annually (Cothern, 1987). A 1992 study by the U.S. Environmental Protection Agency (USEPA) reported that many homes in Wyoming exceeded the recommended level of $4 \mathrm{pCi} / \mathrm{L}$ (picocuries per liter) for indoor air. In Natrona County, 10 percent of the indoor-air levels of radon exceeded $4 \mathrm{pCi} / \mathrm{L}$, whereas in Lincoln County, 51 percent of the indoor-air levels of radon exceeded 4 pCi/L (U.S. Environmental Protection Agency, 1993). One source of radon in indoor air is ground water. Consequently, the U.S. Geological Survey (USGS), in cooperation with Converse County, Laramie Rivers, Platte County, Saratoga-Encampment-

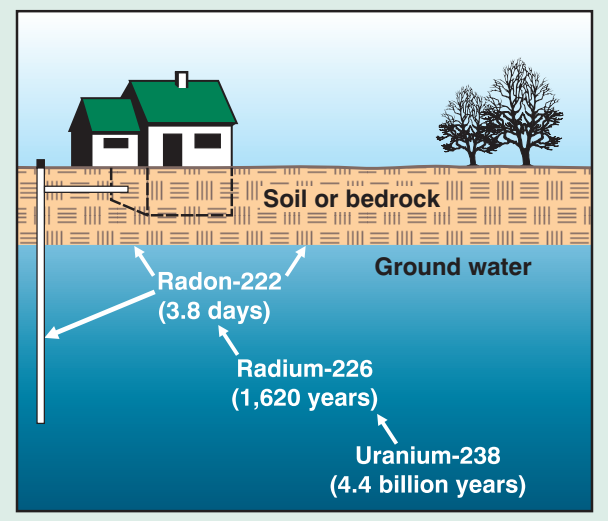

Figure 1. Radon decay chain and half-lives (modified from Clark and Briar, 1993).
Rawlins, and Star Valley Conservation Districts; the Sublette County Public Health Nursing Service; and the town of Torrington, Wyoming, collected water samples from wells in Albany, Carbon, Converse, Goshen, Lincoln, Platte, and Sublette Counties to measure radon concentrations in some of Wyoming's ground water.

\section{WHAT IS RADON?}

Radon is a colorless, odorless, tasteless gas that naturally occurs in rocks, soil, water, and air. Radon is produced by the radioactive decay of uranium-238 to radium-226 (fig. 1). Radium-226 further decays to produce isotopes of radon, including radon-222. Radioactive decay is a natural, spontaneous process in which an atom of one radioactive element breaks down to form another element or isotope. The rate of an isotope's decay is defined by its half-life, or the time it takes for one half of a given amount of the element to decay. Radon-222 (referred to as radon in this report) has a half-life of 3.8 days.

\section{WHERE IS RADON FOUND?}

The ultimate source of radon is uranium and most rocks contain some uranium. Rocks typically contain between 1 and 3 ppm (parts per million) of uranium (Otton, 1992). In Wyoming, some rocks and sediments derived from various rock types can contain higher amounts of uranium. Rock types typically having high amounts of uranium (as much as $100 \mathrm{ppm}$ ) include: granite, light-colored volcanic rocks, dark shales, sedimentary rocks that contain phosphate or uranium deposits, and metamorphic rocks derived from these rocks (Otton, 1992). In addition, sediment and soil derived from these rocks can have high amounts of uranium. Because radon is a gas, it is very mobile in the environment and can easily move through fractures and openings in rocks and into the pore spaces in an aquifer or soil. The amount of radon in ground water is related to several factors, including the amount of uranium available in the source rocks, the location of the radium atom in the mineral grain (how close it is to the grain's surface), and the physical

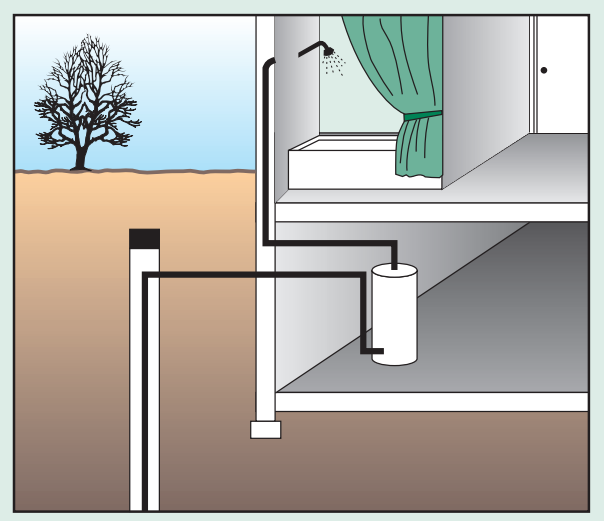

Figure 2. Radon entering a home through a water system (modifed from Otton, 1992).

properties of the aquifer materials, such as porosity. High radon concentrations are most prevalent in water in the eastern United States (Lindsey and Ator, 1996; Zapecza and Szabo, 1988), but high concentrations also have been detected in the Rocky Mountain 
region (Clark and Briar, 1993).

Radon can enter homes from the rocks and soil through cracks, vents, or other openings in basement floors or walls. Radon can also enter homes through a water system (fig. 2). When radon is confined by tightly sealed areas, it can become concentrated.

Homes with private wells are more likely to have increased exposure to radon from water compared to homes that rely on surface water or to homes served by a public ground-water supply. Homes that rely on surface water for their water supply usually do not have radon problems because radon is released from water on contact with the atmosphere. Homes served by large, public groundwater supplies generally have a lower risk of radon exposure because some of the radon is released into the air as a result of pumping, the water is treated, or because some of the radon naturally decays while in the distribution system. People can be exposed to radon from ground water in two ways: 1 ) inhalation of radon that has been released from the water during household activities when the water is heated or agitated, such as showering, washing clothes, or washing dishes; and 2) ingestion by drinking the water. The risk from radon exposure by ingestion is considered much lower than by inhalation.

\section{WHAT DID WE FIND IN WYOMING?}

\section{During 1996-97, the USGS} collected 59 water samples for analysis of radon in ground water in Wyoming (fig. 3). Domestic wells were selected for sampling in seven counties: Albany (11 wells), Carbon ( 7 wells), Converse (6 wells), Goshen (12 wells), Lincoln (10 wells), Platte (6 wells), and Sublette ( 7 wells). Some points in figure 3 are obscured by the close

Table 1. Radon concentrations in ground water in Wyoming, 1996-97 [radon concentration in picocuries per liter]

\begin{tabular}{|ccccc|}
\hline & & \multicolumn{3}{c|}{ Radon concentrations } \\
\cline { 3 - 5 } County & $\begin{array}{c}\text { Number of } \\
\text { samples }\end{array}$ & Minimum & Maximum & Median \\
\hline Albany & 11 & 210 & 8,200 & 890 \\
Carbon & 7 & 610 & 6,100 & 1,100 \\
Converse & 6 & 180 & 2,900 & 1,300 \\
Goshen & 12 & 270 & 1,100 & 540 \\
Lincoln & 10 & 150 & 1,600 & 550 \\
Platte & 6 & 260 & 7,000 & 520 \\
Sublette & 7 & 540 & 1,300 & 930 \\
\hline
\end{tabular}

proximity of wells sampled in Albany, Goshen, and Lincoln Counties. Of the wells sampled, 25 were completed in unconsolidated deposits, 33 were completed in non-granitic bedrock, and 1 was completed in granitic bedrock. Unconsolidated deposits include: 1) alluvial deposits left from streams, consisting of cobbles, gravels, sands, and clays that are loosely arranged; and 2) terrace deposits, also left from streams, which occur as a step-like ledge along a stream margin and mark a former, higher water level. The depth of wells sampled ranged from 20 to 510 feet. Samples were collected using methods described by Koterba and others (1995).

Samples were analyzed using liquid scintillation at the USGS National Water-Quality Laboratory in Arvada, Colorado.

Results of the radon sampling, by county, are shown in table 1 . Concentrations of radon in relation to the seven counties are shown in figure 3 and to the three geologic units in figure 4 . Radon concentrations in ground water samples were variable across the State and ranged from 150 to 8,200 $\mathrm{pCi} / \mathrm{L}$. The median concentration is used to compare radon concen- trations in different counties. When concentrations are ranked from lowest to highest, the median concentration is in the middle. If there were an odd number of samples, the median is in the middle. If there were an even number of samples, the median is the average of the two middle samples. The lowest median radon concentration in ground water was from wells in Platte County (520 $\mathrm{pCi} / \mathrm{L})$, whereas the highest median concentration was from wells in Converse County $(1,300$ $\mathrm{pCi} / \mathrm{L})$. Radon concentrations in ground water from alluvial or terrace deposits ranged from 270 to $3,600 \mathrm{pCi} / \mathrm{L}$ (fig. 4). Radon concentrations in ground water from non-granitic bedrock wells ranged from 150 to $7,000 \mathrm{pCi} / \mathrm{L}$. The lowest radon concentration (150 pCi/L) in ground water was from limestone bedrock in Lincoln County. The highest radon concentration $(8,200 \mathrm{pCi} / \mathrm{L})$ in ground water was from granitic bedrock in Albany County. The USEPA has not established a Maximum Contaminant Level (MCL) for radon in drinking water. The old, proposed MCL of $300 \mathrm{pCi} / \mathrm{L}$ for public-water supplies is currently (1998) under review. For every 


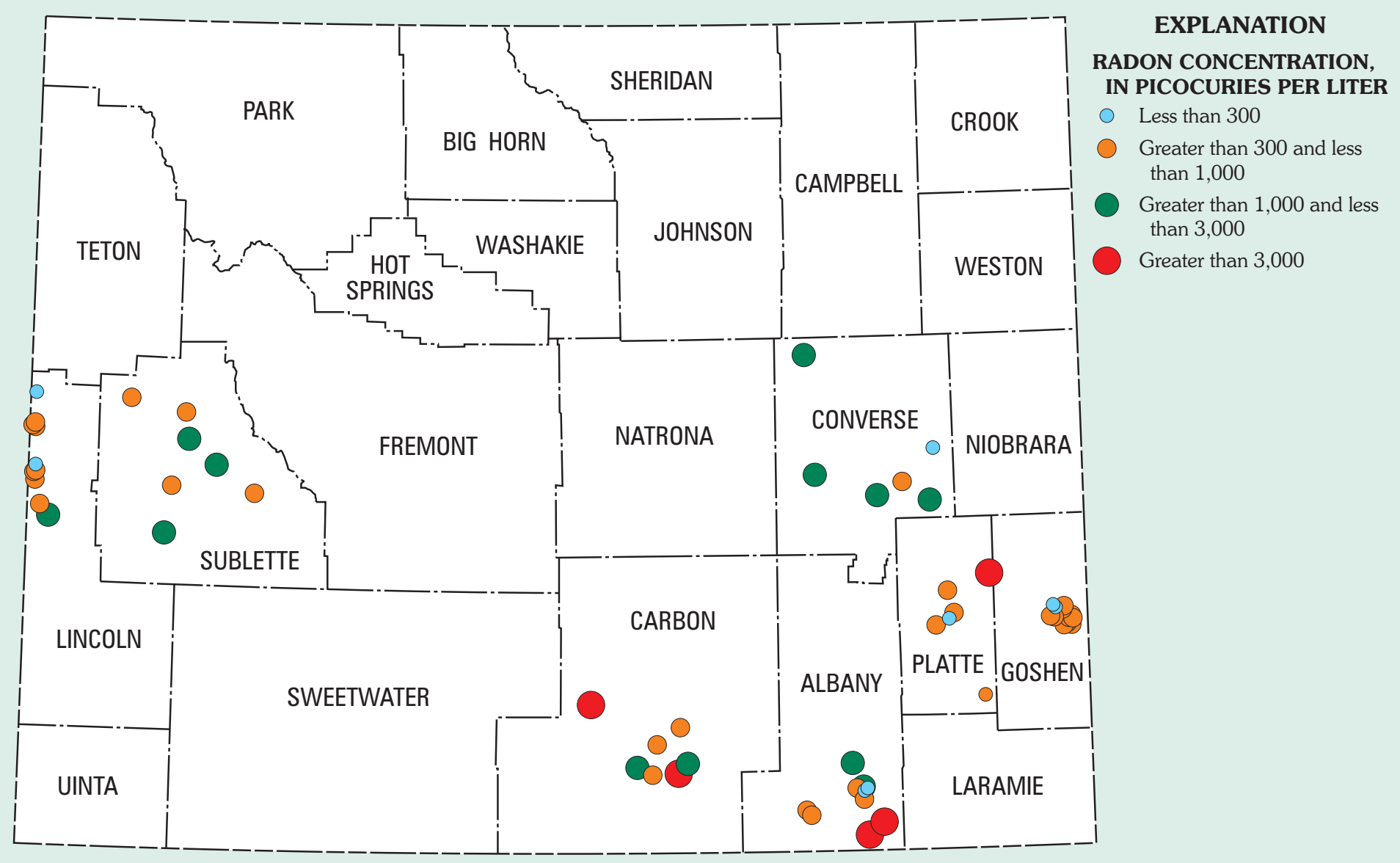

Figure 3. Radon concentrations in ground water in Wyoming, 1996-97.

$10,000 \mathrm{pCi} / \mathrm{L}$ of radon in water, it is estimated about $1 \mathrm{pCi} / \mathrm{L}$ is released to the air (Prichard, 1987).

\section{WHAT CAN I DO?}

The USEPA and Surgeon General recommend homes below the third floor be tested for indoor radon that may be entering the home through the basement (U.S. Environmental Protection Agency and Centers for Disease Control, 1992). In homes where high levels of radon are measured in the air (greater than $4 \mathrm{pCi} / \mathrm{L}$ ) and where water is supplied by a private well, the USEPA recommends that water from the well be tested as a potential source for radon. If high radon concentrations are detected in the water, the most common remediation techniques are aeration and granular activatedcarbon systems. Additional information about radon is available from the Wyoming Department of Health in Cheyenne, Wyoming.

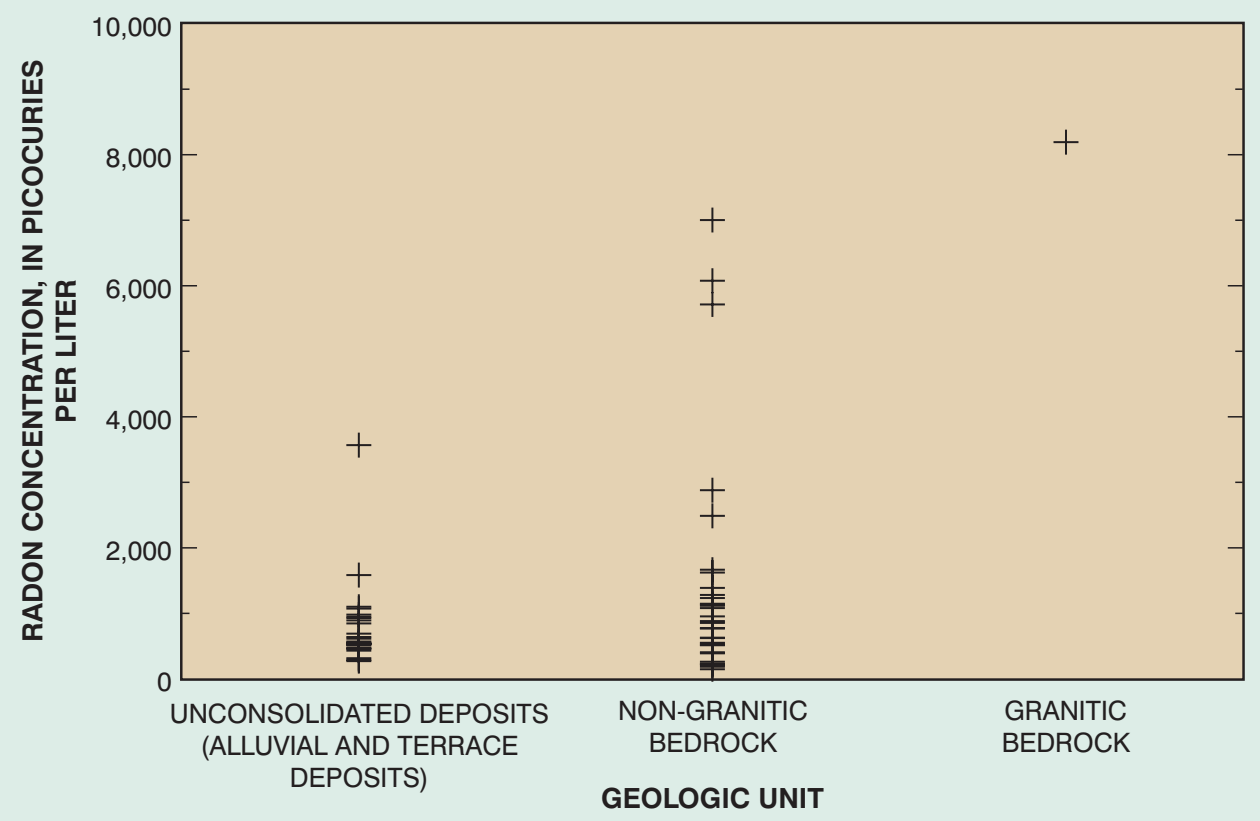

Figure 4. Radon concentrations in ground water from different rock types in Wyoming, 1996-97. 


\section{FURTHER INFORMATION FOR THE READER}

The reader is referred to the following references and internet addresses for additional information concerning radon in ground water and air in the home.

Otton, J.K., 1992, The geology of radon: U.S. Geological Survey.

U.S. Environmental Protection Agency, 1992, Consumer's guide to radon reduction - How to reduce radon levels in your home.

U.S. Environmental Protection Agency, 1993, EPA's Map of radon zones Wyoming.

U.S. Environmental Protection Agency, 1993, Home buyer's and seller's guide to radon.

U.S. Environmental Protection Agency and Centers for Disease Control, 1992, A citizen's guide to radon - The guide to protecting yourself and your family from radon ( $2 \mathrm{~d}$ ed.).

The following Internet/World Wide Web information is also available:

USGS Radon Page:

http://sedwww.cr.usgs.gov:8080/radon/

USEPA Radon Page:

http://www.epa.gov/iaq/radon/

National Safety Council Environmental Health Center, Air Quality Program: http://www.nsc.org/ehc/airqual.htm

\section{For more information contact:} District Chief

U.S. Geological Survey, WRD 2617 E. Lincolnway, Suite B

Cheyenne, Wyoming 82001-5662

Email:

staterep_wy@mailcheyenne.cr.usgs.gov Internet:

http://wyoming.usgs.gov/welcome.html

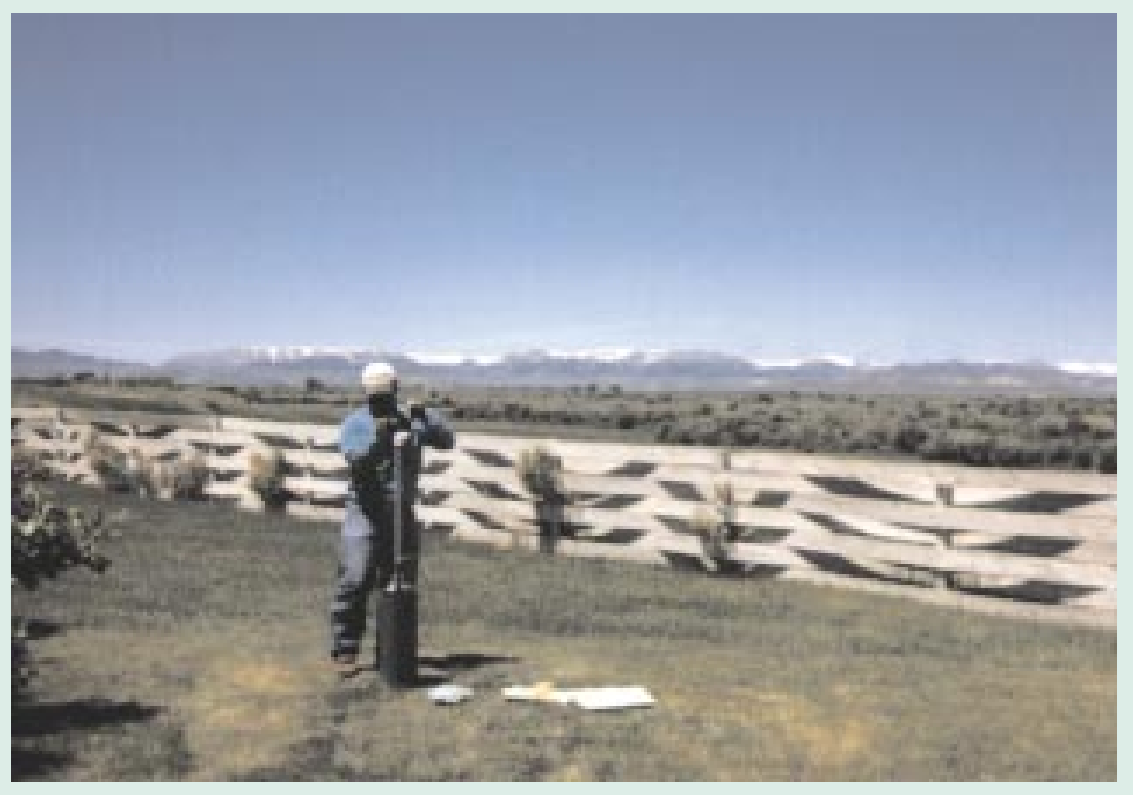

\section{SELECTED REFERENCES FROM TEXT}

Clark, D.W., and Briar, D.W., 1993, Radon in ground water of western Montana: U.S. Geological Survey, Open-File Report 93-64, 2 p.

Cothern, C.R., 1987, Estimating the health risks of radon in drinking water: Journal of American Water Works Association, v. 79, no 4., p. $153-158$.

Lindsey, B.D., and Ator, S.W., 1996, Radon in ground water of the lower Susquehanna and Potomac River Basins: U.S. Geological Survey, Water-Resources Investigations Report 96-4156, 6 p.

Koterba, M.T., Wilde, F.D., and Lapham, W.W., 1995, Groundwater data-collection protocols and procedures for the National Water-Quality Assessment Program - Selection, installation, and documentation of wells, and collection of related data: U.S. Geological Survey Open-File Report 95-398, 69 p.

Otton, J.K., 1992, The geology of radon: U.S. Geological Survey, General Interest Publications of the U.S. Geological Survey, 28 p.
Prichard, H.M., 1987, The transfer of radon from domestic water to indoor air: Journal of American Water Works Association, v. 79, no 4., p. 159-161. Agency, 1992, Consumer's guide to radon reduction - How to reduce radon levels in your home: EPA-402-K92-003, 17 p.

\section{U.S. Environmental Protection} Agency and Centers for Disease Control, 1992, A citizen's guide to radon - The guide to protecting yourself and your family from radon (2d ed.): EPA-402-K92-001, $15 \mathrm{p}$.

1993, EPA's Map of radon zones Wyoming: EPA 204-R-93-003, $32 \mathrm{p}$.

Zapecza, O.S., and Szabo, Zoltan, 1988 , Natural radioactivity in ground water - A review in National Water Summary 1986-Hydrologic events and groundwater quality: U.S. Geological Survey Water-Supply Paper 2325, p. 50-57. and Cheryl A. Eddy-Miller

\section{U.S. Environmental Protection}

